\title{
The impact of the euro adoption on the complexity of goods in Slovenian exports ${ }^{* 1}$
}

\author{
Piotr Gabrielczak ${ }^{2}$, Tomasz Serwach ${ }^{3}$
}

\begin{abstract}
The aim of this paper is to verify the impact of the euro adoption on the complexity of goods in Slovenian exports. To the best knowledge of the authors, it is the first study on the consequences that the elimination of a national currency may have for that feature of trade. According to the Ricardian and Hechscher-Ohlin models of trade, such a policy decision (seen as an example of trade liberalization) may lead to specialization in the production of either more or less sophisticated goods - the outcome depends on the country's technology and factor endowment. At the same time, increased FDI flows may make a particular economy more engaged in international production chains, with an ambiguous influence on export complexity. Given the fact that it is impossible to (a priori) theoretically predict the impact of monetary integration on export complexity, it is reasonable to search for the effects of the integration empirically. The authors used the Synthetic Control Method to compare the actual levels of export complexity in Slovenia after the adoption of the euro with the counterfactual scenario with Slovenia not entering the Eurozone. The results indicate that membership in the European Monetary Union (EMU) led to a temporary increase in the complexity of exported goods.
\end{abstract}

Key words: Eurozone, euro, exports, Slovenia, complexity, synthetic control method, comparative advantage, factor abundance

JEL classification: $C 21, F 14, F 15$

\footnotetext{
Received: 31-01-2017; accepted: 31-05-2017

1 The research project was financed by means of the National Science Centre of Poland (Narodowe Centrum Nauki) granted upon decision number DEC-2014/13/N/HS4/02977 (contract number: UMO-2014/13/N/HS4/02977).

2 Assistant Professor, Faculty of Economics and Sociology, Department of Macroeconomics, 3/5 POW Street, room A416, 90-255 Lodz, Poland. Scientific affiliation: international economics, business cycles. Phone: +48 42635 5058. Fax: +48 42635 5308. E-mail: pgabrielczak@uni. lodz.pl.

3 Assistant Professor, Faculty of Economics and Sociology, Department of International Trade, 3/5 POW Street, room A216, 90-255 Lodz, Poland. Scientific affiliation: international trade, economic growth. Phone: +48 42635 5353.Fax: +4842635 5210.E-mail: serwachtomasz@uni. lodz.pl.
} 


\section{Introduction}

The theory of international trade went through a substantial evolution, from a classical, fully macroeconomic approach, based on comparative advantages, to the so called New Trade Theory, focused on the microeconomic foundations of international trade. In a similar manner, the view on the role of international trade evolved from a general consideration of trade as such to more detailed observations of trade's specific aspects and characteristics. One of the recently explored fields of analysis is the composition of trade, especially export complexity, which is believed to play a significant role in facilitating a country's economic growth, both in terms of its pace and sustainability.

The last half-century has been an era of general globalization, but also regional integration at the same time. Political decisions result in reducing barriers for international economic activity. Entering a monetary union is one of the highest forms of integration, and one which should affect all possible aspects of international trade. It is interesting how joining such a union might influence the export complexity of a small country. We focus on Slovenia as one of the countries to recently access the Eurozone. Therefore, the aim of this article is to verify the impact of the euro adoption on the complexity of goods in Slovenian exports. With that goal in mind, we verified the hypothesis that the adoption of the euro has significantly affected the complexity of exports in Slovenia. There are many possible mechanisms linking monetary integration and export sophistication. Specialization according to comparative advantages and FDI flows may be influenced by the adoption of a single currency and may also affect export complexity. However, the net effect seems to be ambiguous. Still, we are convinced that such an important policy decision has nonnegligible effect for analysed characteristic of trade.

In the second section, we review the literature on the currency union's trade effects and economic complexity. The third section includes a description of the applied methodology (synthetic control method). In the fourth section, we present the data and estimation results. These results are discussed in the fifth section, while the last section concludes.

\section{Literature review}

\subsection{Currency union effects}

The discussion about the benefits of a currency union has been intense since at least Mundell (1961). It has been argued that the elimination of national currencies and the adoption of a single currency may lead to increased trade between integrating countries due to higher price predictability and the lack of conversion costs. However, it was only the creation of the euro that accelerated the empirical verification of that 
hypothesis. Rose (2000) is regarded as probably the first - and a highly controversial study of the trade consequences of currency unions. The author estimated parameters of the gravity model of trade that included the currency union dummy.

Rose (2000) estimates that the currency union effect is high - this form of economic integration increases bilateral trade between member countries by $200 \%$. Such a result seemed implausible, initiating a wave of research on the trade implications of the Eurozone (see, for example, Micco et al., 2003, De Nardis and Vicarelli, 2003, Santos Silva and Tenreyro, 2006, Berger and Nitsch, 2008, Glick and Rose, 2016). Subsequent papers diminished the euro trade effect by dealing with many empirical problems like reverse causality, the existence of zeroes in trade data, time lag before materialization of the effect, and the heterogeneity of member states. All those studies show that the establishment of the Eurozone increased bilateral trade between member states, but the scale of such an increase was milder than expected and ranged in general from 15 to 30\% (see Baldwin, 2006, and Frankel, 2010, for an overview), although several studies found no effect of the Eurozone (see Santos Silva and Tenreyro, 2010).

The synthetic control method, used in our research, has also been applied to verify the euro trade effect ${ }^{4}$. Saia (2016) studied bilateral flows between seven countries that adopted the single currency in 1999. He found that the euro has led to more trade between member states compared to the counterfactual scenario based on the synthetic control groups.

Another strand of the literature focuses on the firm-level effects of adopting the euro. Those papers may provide micro-foundations to the aggregate results from the mentioned studies and usually they focus on the decision of a firm whether to export or not. The framework used in models of a firm's decision to engage in exports (the so called New New Trade Theory or Trade theory with heterogeneous firm) was developed by Melitz (2003). According to our knowledge, however, models of such decisions in the context of nominal exchange rate volatility are still lacking. At the same time, few authors have investigated the role of the level of the nominal exchange rate in a firm's engagement in exports (see, especially, Chaney, 2016). Hence, the only model of trade with heterogeneous firms that directly applies to the eurozone experience is Bergin and Lin (2012), in which the authors focus on the elimination of transaction costs after the formation of the EMU (instead of changes in the nominal value of the currency). Nominal exchange rate volatility could be seen as another source of uncertainty affecting firm-level trade (that field has been developed by, for example, Crozet et al., 2008, and Segura-Cayuela and Vilarrubia,

\footnotetext{
4 The same method was also utilized by Gomis-Porqueras and Puzzello (2015) in their analysis of the impact of the euro on GDP per capita of member states. The same topic was the research interest of Žúdel and Melioris (2016), who also applied the synthetic control method - however, they focused on the case of Slovakia.
} 
2008). For a thorough overview of the links between exchange rates and trade see Auboin and Ruta (2013).

Those studies may be put in the broader context of studies decomposing the euro trade effect, or at least focusing on only some of its aspects. The decision of firms to engage in trade is the basis of the so called extensive margin of trade (the number of exporters/importers or the number of goods in exports/imports). The New Goods Hypothesis has been analysed by, for instance, Baldwin and DiNino (2006), Flam and Nordström (2007) and Nitsch (2011). Other trade consequences of the adoption of a single currency that have been studied are, among others, the pricing policy of exporters (Berman, Martin, Mayer, 2012), the quality of exports (Ito and Okubo, 2016). ${ }^{5}$ To the best of our knowledge there is no study on the impact of the euro adoption on the complexity of exported goods, hence our article fills an important research gap.

Slovenia has not been at the centre of the debate about the euro trade effects, since studies have focused primarily on the first member states. There are, however, exceptions. Aristovnik and Meze (2009) investigated how the introduction of the euro in 1999 affected Slovenian trade as an example of the impact the single currency might have on trade flows with non-member states. They found no permanent effect with a transitory decrease in Slovenian imports from the EMU and an anticipated increase in exports from that country to the Eurozone. Although that finding seems interesting, it does not tell us anything about the consequences of the adoption of the euro by Slovenia and nor by other countries.

In contrast, Cieślik, Michałek and Michałek (2013) studied that issue and utilized a probit model to verify the determinants of export decisions of firms. The authors used firm-level data for Slovenia and Slovakia. They obtained the results indicating that the adoption of the euro by Slovenia increased the propensity of firms from that country to export.

Cieślik, Michałek and Mycielski (2014) also studied the euro's trade effects in new member states. They estimated the panel model using data for a broad range of countries, including Slovenia. They used several specifications of the model, categorizing countries as old members and new members. According to the results, there is no evidence that the adoption of the single currency stimulated bilateral trade between a new member and other countries belonging to the EMU ${ }^{6}$. In another research (Cieślik, Michałek and Mycielski, 2012) they focused on Slovakia and

5 See also Baldwin, DiNino, Fontagné, De Santis and Taglioni (2008), Fontagné, Mayer and Ottaviano (2009), or Berman, Martin and Mayer (2012) for an overview and the simultaneous analysis of the many aspects of trade.

${ }^{6}$ When one includes variables linked to the so called Great Trade Collapse (GTC) of 2008-2009, EMU membership was statistically insignificant. When such a variable is excluded, membership in the EMU negatively affects bilateral trade. 
Slovenia and applied fixed effects, random effects and Hausman-Taylor estimators to assess whether the countries in question experienced trade expansion after the euro adoption (the authors utilized the gravity model of trade). They found no evidence of trade expansion.

\subsection{Export complexity}

Complexity can be understood in two ways: as a technological advancement of the exported goods (Lall, 2000) or as the range of components used for production (Hausmann et al., 2007). The latter is more common. However, both are correlated, as more technologically advanced processes usually require more production stages and more varied inputs.

Hausmann, Hwang and Rodrik (2007) proved that higher complexity of exports is a significant stimulant of economic growth in countries with a moderate national income (small countries), as trade in more processed or advanced goods is more profitable and enables a stronger international competitive advantage. Further research complemented that result by specifying that this effect is especially strong when countries implement a liberal trade policy and tend not to overvalue their real exchange rate (Anand et al., 2012). Hidalgo and Hausmann (2009) also showed that export complexity is correlated with national welfare measured by GDP per capita. Unfortunately, research concerning the importance of export complexity for economic growth is still largely underdeveloped and the initial results were subject to criticism, mainly concerning the utilized complexity measure (Gertler, 2006) ${ }^{7}$.

Apart from facilitating the pace of economic growth or having possible general welfare effects, export complexity is believed to improve a country's resilience to shocks. Koren and Tenreyro (2013) implied that more complex exports can be resistant to supply side shocks. This is because more complex goods, with a wider range of inputs, are less dependent on each single component. Moreover, among the numerous inputs, only limited amount can be specific, which means that most of them can be easily replaced should a supply side shock occur. Having a wide network of contacts also allows decreasing transaction costs of such a substitution.

If export complexity can stimulate economic growth in a small country, then another important question is how to influence complexity. Basically, complexity depends on the range of competences that are available to the national economy (Hidalgo and Hausmann, 2009). This means that export complexity requires not only technological advancement, but also high human capital (Anand et al., 2012). That potential can be improved through educational and R\&D policies. It also

$\overline{7}$ Of course, Gertler's critique refers to an older version of the research, published as an NBER working paper (Hausmann et al., 2005). 
seems that it easier to establish new comparative advantages if the country obtains them close to their initial specialization, with new export products being related to older ones (Hausmann and Klinger, 2007). Some competences, absent on a domestic market, can be internationally transferred (Hidalgo and Hausmann, 2011), which is a natural process e.g. within transnational corporations (Costinot et al., 2009).

Technological development also depends on natural resources. Despite some doubts concerning the possible negative effects of economic overdependence on natural resources, the majority of the research results prove that it has a positive economic outcome (Lederman and Maloney, 2012). It has also been proved that a good institutional environment for entrepreneurship enables the successful implementation of more complicated production processes in the economy, therefore, it stimulates export complexity as well (Costinot, 2009).

Hausmann, Hwang and Rodrik (2007), who should be considered pioneers in research on complexity, suggest a set of possible export complexity determinants, that consists of: area, population, human capital index, rule of law index and GDP per capita. In their approach, area approximates natural resources. Population describes the size of the labour force, while the human capital index presents its quality. GDP per capita is a proxy for the development (technology) level, while rule of law is believed to reflect the institutional development of the domestic market.

The open question is whether economic integration leads to higher complexity of exports. According to our knowledge, there is no study on the effects of such processes, and especially of forming a currency union, on that characteristic of trade flows. There are, however, studies that may shed some light on the issue. In general, after trade liberalization (with the adoption of a single currency being an example of such a process) countries may follow specialization patterns that have ambiguous impact on export complexity. Since the Ricardian comparative advantage is based on a country's technological development, a country that is not close to the technological frontier may concentrate on goods that are less sophisticated with the declining export complexity being the consequence of such a process. Young (1991) showed that trade liberalization makes developing countries specialize in more traditional sectors that exhausted their learning-by-doing possibilities. It is reasonable to assume that such sectors produce less complex products.

Similarly, Heckscher-Ohlin theory predicts that trade patterns depend on a country's factor abundance. Galor and Mountford (2008) modelled countries' accumulation patterns after opening to trade. They found that after lowering trade barriers, developing countries invest less in human capital, hence, they specialize in less advanced sectors. Due to the fact that in 2007 (the year of the accession to the Eurozone) Slovenia had a GDP per capital level equal to $80 \%$ of the 
Eurozone average ${ }^{8}$, it would suggest that after the accession Slovenia should have experienced a decline in export complexity.

On the other hand, the elimination of a national currency may also lead to changes in FDI patterns across countries. Xu and Lu (2009), Harding and Javorcik (2012) and Eck and Hubert (2016) found that FDI inflows result in higher export quality and sophistication. Since economic integration may lead to an increase in FDI from third countries (see Antras and Foley, 2011), it is reasonable to think of Slovenia as a recipient of FDI from non-member states.

The adoption of the euro by Slovenia may be seen as a unique example of economic integration resulting in trade and factor movement liberalization. Given the inconclusiveness of the literature on the effects of such processes, we tried to verify whether the adoption of the euro had an impact on export complexity in Slovenia.

\section{Methodology}

The problem of the impact of accessing the Eurozone on the complexity of Slovenian exports is a part of a larger discussion about causal inference when one uses panel data. Such inference is based on modelling a country-specific effect, but with a time-varying coefficient. Models typically applied in such cases are fixed effects models (FE), difference in difference models (DD), or models with lagged dependent variable (LDV). However, they are only able to control for countryspecific and time-varying effects separately, while in reality the process includes interaction, and might be as complicated as in model (1).

$$
W_{i t}=X_{i t} \beta+Z_{i} \theta_{t}+\lambda_{t} \mu_{i}+\varepsilon_{i t}
$$

Where $X_{i t}$ denotes independent variables with stable parameters from vector $\beta$ and $Z_{\mathrm{i}}$ denotes covariates with time-varying parameters $\theta_{\mathrm{t}}$, while $\varepsilon_{\mathrm{it}}$ stands for an error term. In this model, $\lambda_{\mathrm{t}} \mu_{\mathrm{i}}$ represents heterogeneous responses to multiple unobserved factors, which is the problematic interaction. In the FE or DD models these responses can only be represented by a linear expression of two types of factors $\delta_{t}+$ $\alpha_{i}$, which are only special cases of the $\lambda_{\mathrm{t}} \mu_{\mathrm{i}}$ response.

Abadie, Diamond and Hainmueller (2010) came up with a solution to this problem, under the restriction of the country-specific effect being reserved to only one country and the time-varying effect being continuous after its introduction. In

\footnotetext{
${ }_{8}^{8}$ Based on OECD data at current prices with PPP. The Eurozone was defined as the block of 19 countries, hence, it undervalued the GDP per capita level of the 2007 Eurozone which was then formed by the most economically advanced countries of the European Union. It implies that the comparison of the income per person in Slovenia and the 2007 Eurozone would reveal even bigger differences.
} 
fact, these restrictions mean that their approach is ideal to observe the effects of a standing policy decision introduced in a particular year in a certain country. Their approach is known as the synthetic control method (SCM).

Following Abadie, Diamond and Hainmueller's (2010) description of the method, let us assume that we observe $\mathrm{J}+1$ units (countries) in T periods (years). One of the units, and we can assume that it is the unit enumerated by zero (leaving units $1, \ldots, \mathrm{J}$ in the control sample), is subject to a treatment (e.g. political decision) in year $\mathrm{T}_{0}$, so the effects of interference are observed in unit zero for periods $\mathrm{T}_{0}, \ldots, \mathrm{T}$, while they remain unobserved in periods $0, \ldots, \mathrm{T}_{0}-1$. In general, we can formulate these conditions as below.

$$
\begin{aligned}
& Y_{i t}=Y_{i t}^{N}+\Delta_{i t} D_{i t} \\
& \Delta_{i t}=Y_{i t}^{I}-Y_{i t}^{N} \\
& D_{i t}=\left\{\begin{array}{l}
1 \text { if } i=0 \text { and } t=T_{0}, \ldots, T \\
0 \text { otherwise }
\end{array}\right.
\end{aligned}
$$

Where $Y_{i t}$ is the observed variable which might have two outcomes: $Y_{i t}{ }^{N}$ is the outcome without the effect of interference (neutral) and $\mathrm{Y}_{\text {it }}{ }^{\mathrm{I}}$ is the outcome with interference included (interfered). $\mathrm{D}_{\mathrm{it}}$ is a binary switching function and $\Delta_{\mathrm{it}}$ is the difference of two potential outcomes for country $i$ in period $t$.

The SCM is based on the idea that we can model $\mathrm{Y}_{\mathrm{it}}^{\mathrm{N}}$ and the treatment effect is the $\Delta_{\mathrm{it}}$ difference between the observed value of Y (which in the post-treatment period is, in fact, the interfered outcome) and its theoretical neutral value. The factor model of the neutral outcome is as follows:

$$
Y_{i t}^{N}=\delta_{t}+Z_{i} \theta_{t}+\lambda_{t} \mu_{i}+\varepsilon_{i t}
$$

Where $\delta_{\mathrm{t}}$ is an unobserved time-varying (but common to all units) factor, while $Z_{\mathrm{i}}, \theta_{\mathrm{t}}, \lambda_{\mathrm{t}}, \mu_{\mathrm{i}}$ and $\varepsilon_{\mathrm{it}}$ are interpreted as in (1), with the reservation that the vector dimensions need to be controlled so that vector products $Z_{\mathrm{i}} \theta_{\mathrm{t}}$ and $\lambda_{\mathrm{t}} \mu_{\mathrm{i}}$ are well defined as scalars. Let us assume, e.g., that $Z_{\mathrm{i}}$ is a $(1 \mathrm{xr})$ vector and $\theta_{\mathrm{t}}$ is a (rx1) vector, while $\lambda_{\mathrm{t}}$ is a (1xs) vector while $\mu_{\mathrm{i}}$ is a (sx1) vector. It is worth noting that by adding the assumption that $\lambda_{t}$ is constant in time, equation (5) is transformed into a standard DD/FE model, thus SCM can be treated as a generalized form of the DD approach.

In the case of panel data, we can base our conclusions on the post-treatment outcomes for unit zero, both on the treated unit itself before treatment and on the control sample of the units that were not subject to treatment. The aim of the SCM 
method is to use pre-treatment data to construct a set of weights which could be used to produce a synthetic treated unit as a linear combination of the control units. It is crucial to choose a control set that forms a kind of band for the actual observed outcome values, as the SCM, by its construction, cannot successfully create suitable counterfactuals for outliers or units with extreme values of the measured outcomes. The first reason for that is that outliers usually are characterized by different patterns of outcome generation. The second is more technical: for practical reasons, we impose a condition that all the weights must be non-negative and sum up to 1 , thus, we determine that the synthetic unit is within the convex hull of the control set (Fremeth et al., 2013: 13). Considering these reservations, we can define potential controls $\mathrm{W}$ as in (6).

$$
W=\left(w_{1}, \ldots, w_{J}\right) ; \forall_{i=1, \ldots, J} w_{i} \geq 0 \wedge \Sigma_{i=1}^{J} w_{i}=1
$$

Let us now consider the vectors of country-specific characteristics $Z_{i}$ and a family of linear functions of pre-treatment outcomes $Y_{i}^{k}$, with $k=1, \ldots, m$ and $m \geq s$ (a relatively large family). Let us now assume that we can choose a control vector $\mathrm{W}^{*}$ that meets condition (7).

$$
W^{*}=\left(w_{1}^{*}, \ldots, w_{J}^{*}\right) ; \Sigma_{i=1}^{J} w_{i}^{*} Z_{i}=Z_{0}, \Sigma_{i=1}^{J} w_{i}^{*} Y_{i}^{1}=Y_{0}^{1}, \Sigma_{i=1}^{J} w_{i}^{*} Y_{i}^{m}=Y_{0}^{m}
$$

In that case, we receive an approximately unbiased estimator of the $\Delta_{\text {it }}$ for the treated country.

$$
\widehat{\Delta}_{0 t}=\mathrm{Y}_{0 t}-\Sigma_{i=1}^{J} w_{i}^{*} Y_{i t}, t=T_{0}, \ldots, T
$$

Of course, in reality, it might be impossible to find a control vector $\mathrm{W}^{*}$ that could meet condition (7). However, the estimator holds if we determine a control vector $\hat{W}$ that solves the minimization problem (9) when assumption (6) stands.

$$
\widehat{W}=\min \left\|X_{0}-X_{J} W\right\|
$$

In (9) the problem is expressed in a matrix notation, in which $\mathrm{X}_{0}$ stands for a $(\mathrm{r}+\mathrm{m}$ $\mathrm{X} 1$ ) vector of characteristics of the treated country, defined as $\left(Z_{0}, Y_{0}{ }^{1}, \ldots, Y_{0}{ }^{m}\right)$ '. $X_{J}$ is a $(\mathrm{r}+\mathrm{m} \times \mathrm{J})$ matrix of the same characteristics for the $\mathrm{J}$ control sample countries.

In a more operational form, optimization problem (9) can be rewritten as (10), where the distance representing discrepancy between $\mathrm{X}_{0}$ and $\mathrm{X}_{\mathrm{j}} \mathrm{W}$ can be expressed using $\mathrm{V}$, which is a $(\mathrm{r}+\mathrm{m} \times \mathrm{r}+\mathrm{m})$ symmetric and positive semi definite matrix. In terms of interpretation, $\mathrm{V}$ measures the relative importance of characteristics included in the $\mathrm{X}_{0}$ vector and $\mathrm{X}_{\mathrm{J}}$ matrix (Campos, Coricelli and Moretti, 2014, p. 10)

$$
\widehat{W}=\min \left\{\left(X_{0}-X_{J} W\right)^{\prime} V\left(X_{0}-X_{J} W\right)\right\}
$$


There are many ways to choose matrix V, but the standard way, utilized by STATA when performing the SCM procedure "synth" command, is to compose it in a way that minimizes the mean squared error in the pre-treatment period.

\section{Empirical data and analysis}

\subsection{The complexity of Slovenian exports}

Export complexity can be evaluated with different measures. The simplest solution is to determine which product groups are to be considered complex (e.g. high-tech) and to measure their share in exports (Lall, 2000). A similar but more advanced approach is to produce a synthetic index that would be able to assess the average complexity of the exported goods.

Hausmann, Hwang and Rodrik (2007) suggested such an index - EXPY. It is based on an average of the PRODY indices for all the exported goods, weighted with their share in a country's export. PRODY are product ubiquity indices, describing how common these goods are in world trade. The assumption is that if country's export stream is, on average, composed of more unique products (higher PRODY), it is also more advanced and complex.

In our analyses, we chose another measure, the Economic Complexity Index (ECI), provided by the Atlas of Economic Complexity (AEC) - a project conducted by the Center for International Development at Harvard University. It is an index based on similar assumptions as EXPY, however, it is more advanced. Product ubiquity is not simply measured by its share in world trade, but by the number of countries displaying a comparative advantage in the good.

The ECI varied in Slovenia during the period 1995-2014, reaching a maximum level (1.725) in 2004 and a minimum level (1.443) in 2012. As Figure 1 illustrates, one can decompose the actual values of that indicator, obtaining its cyclical component and trend (such a decomposition was generated by the application of the Hodrick-Prescott filter with usual parameters for yearly data). 
Figure 1: ECI and its trend - Slovenia, 1995-2014

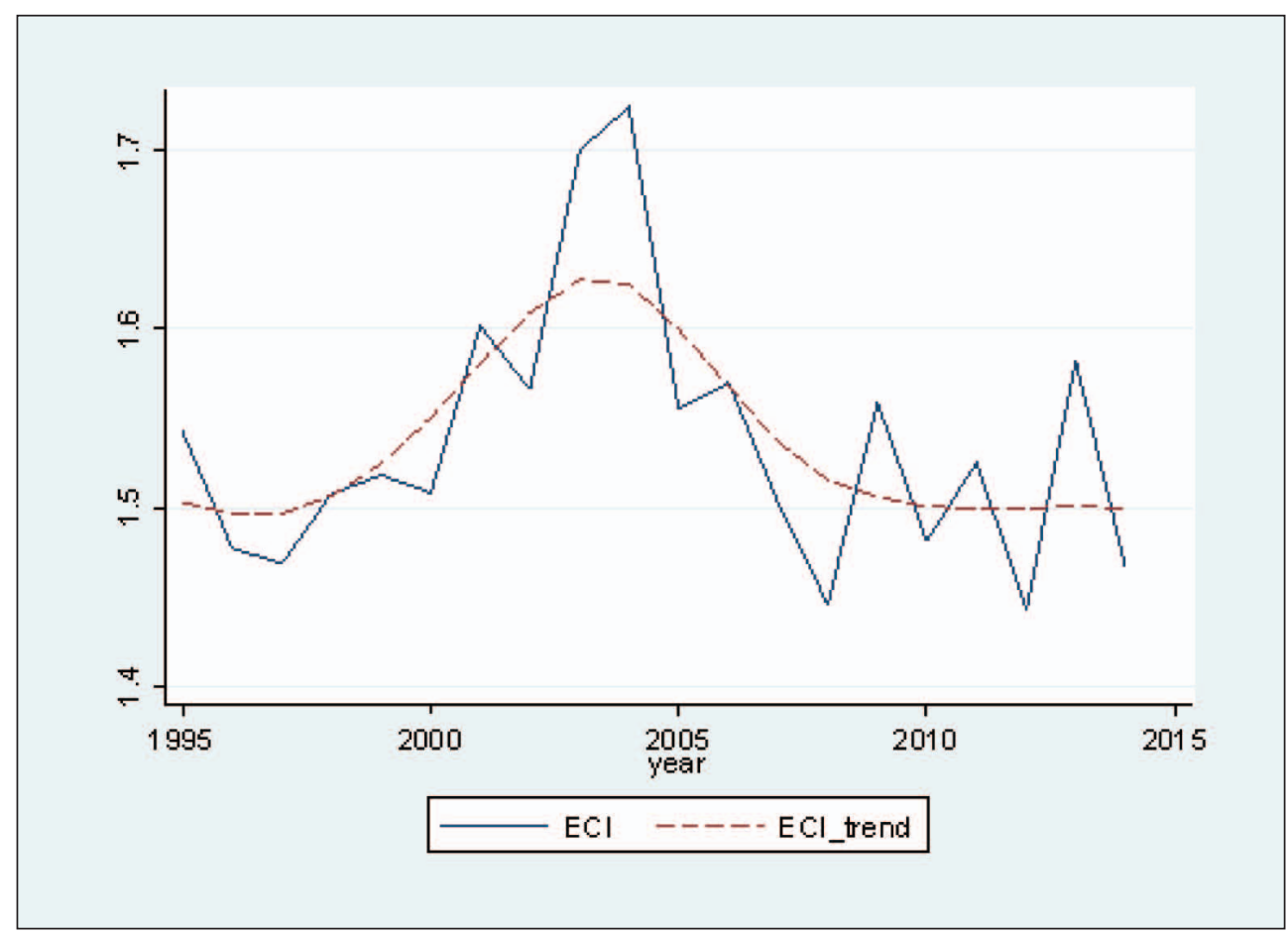

Source: Authors' calculation

During the first years of the timeframe of our analysis, ECI in Slovenia grew from 1.469 (in 1997) to 1.725 (in 2004). The trend component itself indicates that strong upward tendency in the data. Surprisingly, the maximum level of that component was achieved in 2003, although ECI reached a peak a year later (hence, the value of the indicator in 2004 was significantly affected by a transitory shock) ${ }^{9}$.

Starting in 2003/2004, Slovenia has experienced a decline of ECI. The trend component had been characterized a stable decrease until 2008, plateauing since then. As the trend has become stable and the cyclical component has been extremely volatile throughout the analysed period, the actual (aggregated) value of ECI has varied since 2008.

\footnotetext{
9 Investigating the so called Pass-On Trade (simultaneous exports and imports in identical products at the firm level) in Slovenia, Damijan, Konings and Polanec (2013) found patterns similar to the behaviour of the trend component of ECI. We believe that it reflects the importance of engagement in international production chains for Slovenian trade. Increased participation in such chains may lead to a two-way trade in the same product (and a firm acts as an intermediary within the whole network). At the same time, that engagement may stimulate technological and quality upgrading of products that are sent to the next link in the production chain, leading to higher export complexity.
} 
Dividing the timeframe of our analyses into sub-periods is also revealing (see Tables 1 and 2). Since the adoption of the euro, Slovenia has achieved a lower average value and lower volatility of ECI (compared to the whole sample and subperiods before the adoption of the single currency and before the EU accession).

Table 1: ECI in Slovenia - descriptive statistics

\begin{tabular}{|l|c|c|c|c|}
\hline Period & $\begin{array}{c}1995-2014 \\
\text { (the whole } \\
\text { sample) }\end{array}$ & $\begin{array}{c}2007-2014 \\
\text { (after the } \\
\text { adoption of the } \\
\text { euro) }\end{array}$ & $\begin{array}{c}1995-2006 \\
\text { (before the } \\
\text { adoption of the } \\
\text { euro) }\end{array}$ & $\begin{array}{c}1995-2003 \\
\text { (before EU } \\
\text { accession) }\end{array}$ \\
\hline Mean & 1.537 & 1.501 & 1.562 & 1.543 \\
\hline Standard deviation & 0.075 & 0.052 & 0.081 & 0.072 \\
\hline Coefficient of variation & $4.90 \%$ & $3.43 \%$ & $5.16 \%$ & $4.68 \%$ \\
\hline
\end{tabular}

Source: Authors' calculation

The data on trends indicate similar patterns. The mean and standard deviation has decreased since the adoption of the euro. Lower volatility is especially worth highlighting - the standard deviation during 2007-2014 was only 0.014 (that means fluctuations around the mean within the $\pm 0.92 \%$ interval). As we have mentioned, the trend component has stabilized since 2008, affecting the values of the standard deviation and the coefficient of variation.

Table 2: The trend component of ECI in Slovenia - descriptive statistics

\begin{tabular}{|l|c|c|c|c|}
\hline Period & $\begin{array}{c}1995-2014 \\
\text { (the whole } \\
\text { sample) }\end{array}$ & $\begin{array}{c}2007-2014 \\
\text { (after the } \\
\text { adoption of the } \\
\text { euro) }\end{array}$ & $\begin{array}{c}1995-2006 \\
\text { (before the } \\
\text { adoption of the } \\
\text { euro) }\end{array}$ & $\begin{array}{c}1995-2003 \\
\text { (before EU } \\
\text { accession) }\end{array}$ \\
\hline Mean & 1.539 & 1.512 & 1.557 & 1.544 \\
\hline Standard deviation & 0.046 & 0.014 & 0.051 & 0.051 \\
\hline Coefficient of variation & $2.99 \%$ & $0.92 \%$ & $3.28 \%$ & $3.29 \%$ \\
\hline
\end{tabular}

Source: Authors' calculation

It should be clearly stated that one should not infer that the adoption of the euro led to the decrease of ECI in Slovenia (or even the decrease of its trend component). The sub-period 2007-2014 was plagued by events like the sub-prime crisis (with the resulting global financial crisis) and the so called Global Trade Collapse. What is more, accession to the EU might have had lagged implications for Slovenian exports. That is why we adhered to more scrutinized analysis that is presented in the following section. 
It is also worth noting that one may analyse the observed phenomena through the lens of the New New Trade Theory. According to Melitz (2003), trade liberalization in the form of increased number of trade partners (like in the case of the EU accession) leads to lower number of enterprises and, especially, exporters. This is a result of growing role of the economies of scale on a bigger common market with more competition for production factors. Putting that into the context of Slovenian exports complexity, it means that the pool of firms that could cooperate (and by doing so, produce more complex goods) was smaller after the EU entry, resulting in lower ECI (or at least lower ECI dynamics).

In a similar mechanism based on competing for production factors, in the Melitz (2003) model lower trade costs (as in the case of the euro adoption) lead to a decrease of the total number of firms, but a bigger amount of exporters. Since the number of potentially cooperating firms is still small, it means that ECI (dynamics) should be rather low. However, the further fall is prevented due to learning opportunities - having access to foreign markets, firms become more productive (see Yeaple, 2005) and are able to produce more sophisticated goods.

\subsection{The data used for SCM procedure}

We employed the SCM procedures to determine whether joining the Eurozone had an influence on the complexity of the goods exported by Slovenia. We chose ECI to measure export complexity, but since it tends to be subject to significant volatility, while we were interested in analysing stable paths of complexity development, we focused on the Hodrick-Prescott filtered trend of the ECI.

Our choice of the time-varying covariates $\left(\mathrm{Z}_{\mathrm{i}}\right)$ of the observed the ECI was inspired by Hausmann, Hwang and Rodrik (2007). Therefore, we included information on population, real GDP at constant prices (effectively used as GDP per capita) and Human Capital Index provided by the Penn World Table, version 9.0 (Feenstra et al., 2015). Data on the countries' area came from CEPII GeoDist Database (Mayer and Zignago, 2011), and data on the Rule of Law Index estimates were drawn from the World Bank's Worldwide Governance Indicators database.

The first main identification assumption of the SCM is that the variables used as pre-treatment characteristics should be able to approximate the path of the treated unit, but at the same time they should not anticipate the effect of intervention (Campos et al., 2014: 11). In that matter, Hausmann, Hwang and Rodrik's (2007) selection of variables seems to be well fitted to economic theory, which indicates good approximation of the treated unit's path. As for the problem of the possible anticipation of the intervention, while population and area can be easily treated as free from such risk, it seems impossible to find a typically economic variable that would not anticipate entering the Eurozone, especially since Slovenia joined 
the ERM II mechanism in 2004, which was a clear signal for the most possible immediate future. Furthermore, integration is a continuous process, not a zeroone switch (Campos et al., 2014), thus, anticipation is an immanent element. Nevertheless, we believe that the Human Capital Index (being mostly dependent on the system of education) and the Rule of Law Index (as a derivative of social and political factors that seem to be largely independent of the change of legal tender) evolved with no more than minimal anticipation effects. The only really problematic variable is GDP per capita, but it seems to be so basic a welfare indicator that it could not be omitted when matching the countries is involved.

The second assumption claims that the countries used in the control sample should not be affected by the treatment, neither directly nor indirectly (Campos et al., 2014). That is why for the donor pool our research utilizes non-European countries (10 countries: Australia, Canada, Chile, Israel, Japan, Korea, Mexico, New Zealand, Turkey and the USA) and European countries that are outside European Union (2 countries: Norway and Switzerland) ${ }^{10}$. Our choice of control sample was limited by the availability of data, especially about the ECI.

Finally, to increase the fit between the model and the real values of the ECI, we have also included observations of the ECI from the pre-treatment period. These observations work as a $\mathrm{Y}_{0}^{\mathrm{k}}$ type linear function of pre-treatment outcomes. If fitting pre-treatment ECI is the key to create synthetic Slovenia, it might seem tempting to use the outcomes from all the pre-treatment years as control variables. However, Kaul, Klößner, Pfeifer and Schieler (2016) prove that doing so makes all the other covariates insignificant, as the synthetic counterfactual is then fitted only according to pre-treatment outcome values. If the covariates are important explanatory variables for the variation of the outcome, then such a situation might lead to a growing bias in the post-treatment period. That is why they suggest using either the average value of the pre-treatment outcomes or just a few values from the pre-treatment period, preferably the last ones. Our slightly different choice was dictated by the relatively large volatility of the ECI values in Slovenia - we wanted to control for the turning points of the long-term trends. Thus, we tried using ECI observations from the first year of the sample period and the last pre-treatment period to make sure that synthetic Slovenia is not shifted at the boundaries of the pre-treatment period. We also included local extreme values of the ECI trend to facilitate good fitting in the turning points.

\footnotetext{
${ }^{10}$ Despite that assumption, we also conducted our research with an alternative control group with all mentioned countries and, additionally, Czech Republic, Hungary and Poland. These three countries entered the EU in 2004, like Slovenia, yet have not adopted the euro. The results were similar to those obtained by utilizing the basic (non-EU) control group. However, the inclusion of these EU countries may lead to the situation when the control group could be affected by the treatment and that is why we decided to describe in the article only estimations based on the narrower control group. The alternative results are available on request.
} 
Piotr Gabrielczak, Tomasz Serwach • The impact of the euro adoption...

Table 3: Names and abbreviations used in the research to address variables and countries

\begin{tabular}{|c|c|c|}
\hline \multicolumn{3}{|c|}{ Variables } \\
\hline Name & Description & Source \\
\hline ECI & Economic Complexity Index & Atlas of Economic Complexity \\
\hline HCI & Human Capital Index & $\begin{array}{l}\text { Penn World Tables } 9.0 \text { (Feenstra et } \\
\text { al., 2015; further in the table: PWT) }\end{array}$ \\
\hline Population & Population in millions & PWT \\
\hline Area & Area in square km & $\begin{array}{l}\text { CEPII GeoDist (Mayer and Zignago, } \\
\text { 2011) }\end{array}$ \\
\hline rGDPpc & $\begin{array}{l}\text { Real GDP at constant } 2011 \text { national } \\
\text { prices (in mln 2011USD) divided by } \\
\text { the country's population }\end{array}$ & PWT \\
\hline RoL & Rule of Law Index: estimates & $\begin{array}{l}\text { Worldwide Governance Indicators, } \\
\text { World Data Bank }\end{array}$ \\
\hline XXX_trend & $\begin{array}{l}\text { Suffix referring to the fact that } \\
\text { the variable XXX has been rid of } \\
\text { the cyclical component with the } \\
\text { Hodrick-Prescott filter }\end{array}$ & Own elaboration \\
\hline RMSPE & Root Mean Squared Prediction Error & Own elaboration \\
\hline RMSPE \% & $\begin{array}{l}\text { Root Mean Squared Prediction Error } \\
\text { in reference to the mean average } \\
\text { pre-treatment outcome (in \%) }\end{array}$ & Own elaboration \\
\hline \multicolumn{3}{|c|}{ Donor pool (research units) } \\
\hline Number & \multicolumn{2}{|c|}{ Country name with codes } \\
\hline 1 & \multicolumn{2}{|l|}{ AUS - Australia } \\
\hline 2 & \multicolumn{2}{|l|}{ CAN - Canada } \\
\hline 3 & \multicolumn{2}{|l|}{ CHE - Switzerland } \\
\hline 4 & \multicolumn{2}{|l|}{ CHL - Chile } \\
\hline 5 & \multicolumn{2}{|l|}{ ISR - Israel } \\
\hline 6 & \multicolumn{2}{|l|}{ JPN - Japan } \\
\hline 7 & \multicolumn{2}{|l|}{ KOR - Republic of Korea } \\
\hline 8 & \multicolumn{2}{|l|}{ MEX - Mexico } \\
\hline 9 & \multicolumn{2}{|l|}{ NOR - Norway } \\
\hline 10 & \multicolumn{2}{|l|}{ NZL - New Zealand } \\
\hline 11 & \multicolumn{2}{|l|}{ SLN - Slovenia (the treatment unit) } \\
\hline 12 & \multicolumn{2}{|l|}{ TUR - Turkey } \\
\hline 13 & \multicolumn{2}{|l|}{ USA - United States of America } \\
\hline
\end{tabular}

Source: Authors' calculation 
We executed the SCM procedure on a pool of 13 countries (treatment unit included). We used data from 1995-2014. Our treatment unit was Slovenia and the treatment period was 2007 - the year in which Slovenia turned to the euro as its currency. Table 3 presents variable names and numeric symbols of the control pool countries.

The complete set of data, with all observations, is available on request.

\subsection{Estimation results}

In the paper, we do not present all of the estimations conducted - just a sample of them to illustrate best our findings. We used 'synth' command for STATA to obtain our results.

First of all, when the ECI was filtered and its trend obtained, it turned out that it has two local extremes in the pre-treatment period: a minimum in 1996 and a maximum in 2003. Even though we focused on the ECI trend, in the first stage we used all the data on covariates in their primal form (without filtering).

Figure 2 presents the results based on the unfiltered Hausmann, Hwang and Rodrik (2007) suggestions. In the first variant, we control for pre-treatment ECI levels using only data from 1995, 1996, 2003 and 2006, which reflect the edges and extremes of the pre-treatment outcomes.

Figure 2: SCM procedure results with trend component of the ECI and unfiltered covariates

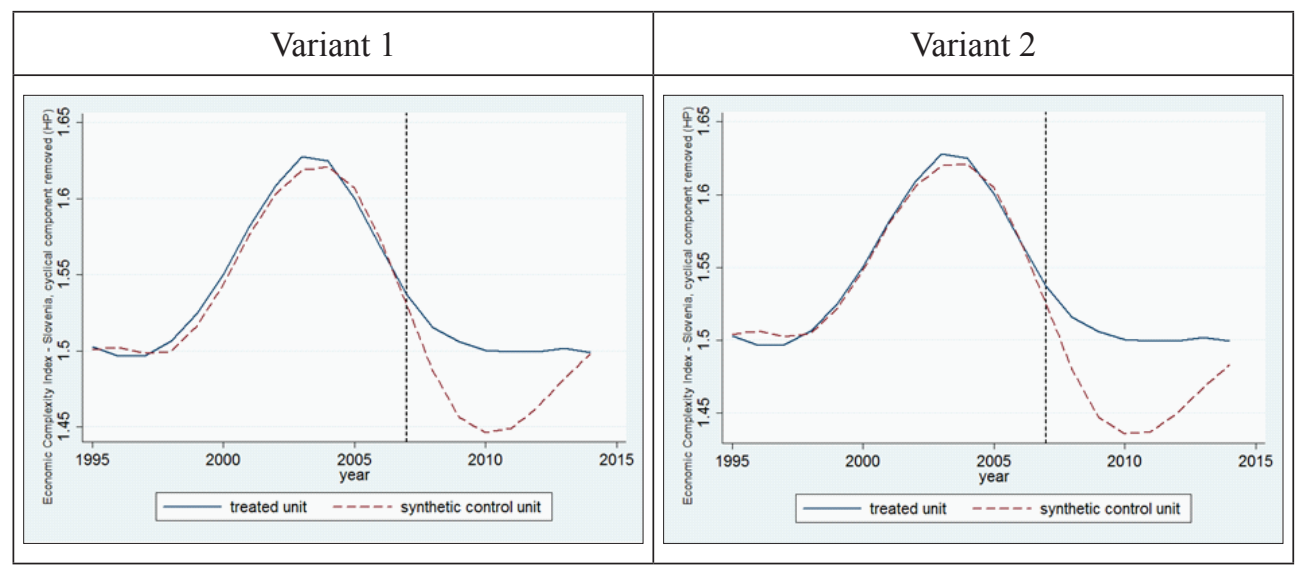

Source: Authors' calculation

However, to test if strengthening such a control could significantly improve the SCM procedure, we exploited a second approach, joining the previously mentioned observations into two connected sub-periods (though each year controlled 
independently); the beginning of the pre-treatment period was 1995-1996 and the end -2003-2006. This approach was presented in the second variant.

The covariates used in the research at the first stage were unfiltered, as we believed that the ECI, even filtered, reacts to changes of the actual values of the presented covariates, not necessarily the purified ones. However, at the second stage, we decided to look at more long term, stable factors and we have filtered data on the Human Capital Index, the Rule of Law Index and real GDP per capita. Only area and population, which are typically stable (or even constant, at least in the research period) in fact needed no filtering.

Figure 3 presents our estimations with trends. Again, we consider two variants of the pre-treatment outcome specification. Variant 3 controls only for the extremes and edges of the pre-treatment period outcomes, while variant 4 binds them into two connected sub-periods.

Figure 3: SCM procedure results with trend component of the ECI and filtered covariates

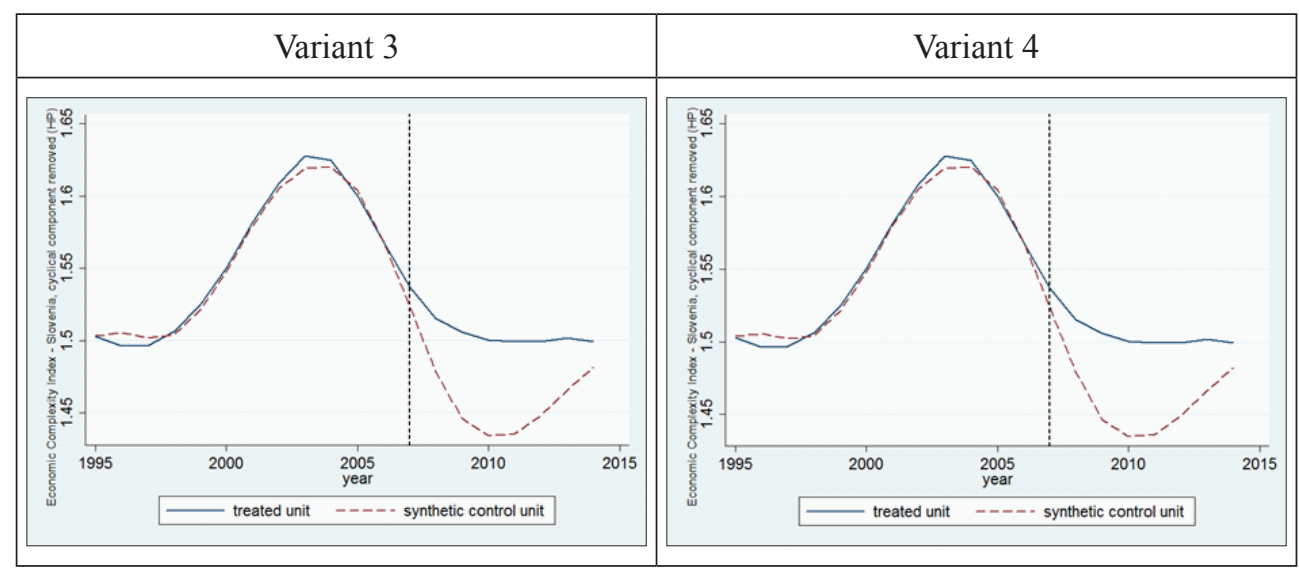

Source: Authors' calculation

As stated in section 4.2, matching with the full set of pre-treatment outcome observations is dangerous, because it can lead to a bias of the post-treatment synthetic predictions. However, in order to have a wider range of possible controls to compare, we also tried a variant with all 1995-2006 values of the filtered ECI. Of course, since in such a case technical matching intercepts all the significance from the characteristics of the donor pool units, we omitted any other control covariates. The results are presented in Figure 4. 
Figure 4: SCM procedure results with trend component of the ECI and full pretreatment outcome matching

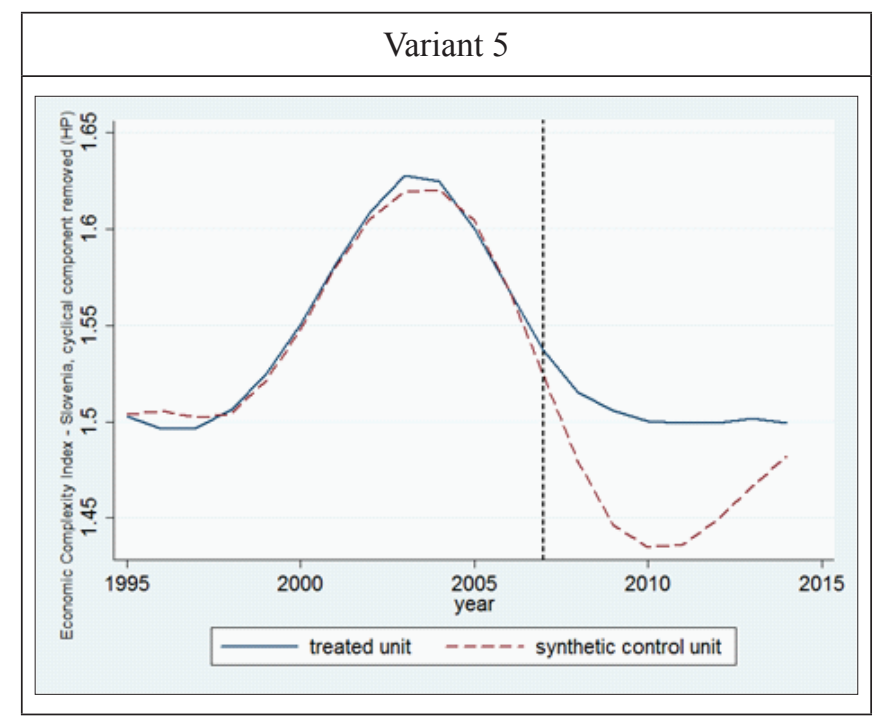

Source: Authors' calculation

The first observation is that the prediction errors are generally small (and obviously smaller when utilizing more pre-treatment ECI values). The treated and synthetic characteristics are close to each other, apart from area, population and the Rule of Law index. However, the donor pool is dominated by countries larger that Slovenia, thus, overestimation of at least one of two parameters, population or area, was expected. In consequence, area (population) is slightly (largely) overestimated. The surprising result is low synthetic Rule of Law Index. A large error of the synthetic counterfactual might indicate that, in fact, the Rule of Law Index is not strongly correlated with the ECI values.

All the presented SCM results demonstrate the same pattern of difference between the synthetic and actual values of filtered ECI. We believe that when Slovenia joined the EU, the complexity of its exports started to decrease due to the fact that it was a relatively less developed EU member state (in comparison to the "old" $15 \mathrm{EU}$ member states) and its comparative advantages in reference to its European partners were manifested in less technologically advanced sectors. Entering the eurozone helped stop the downward trend initiated in 2003 and prevented Slovenian ECI from dropping below 1.45 in 2010.

The trend for synthetic Slovenia did not undergo a rebound before 2010, reaching levels close to the actual values only at the end of the sample period. At the same time, the real trend of the ECI dropped minimally after 2007 and was rather constant 
in the last five observed years. It seems then that joining the eurozone facilitated the pace of adjustment which otherwise would have lasted much longer but, all in all, would probably have led to the present levels of Slovenian exports' complexity. Such an acceleration might have been caused by stronger integration within the eurozone, which might have led to the quicker establishing of stable comparative advantages, resulting in a more efficient formation of export composition.

\subsection{Robustness}

In order to verify the robustness of our results, a placebo test - suggested by Abadie, Diamond and Hainmueller (2010) - was conducted. In such a test, the same SCM procedure was applied to every unit belonging to the donor pool. The procedure resembles a permutation test. The first step is the exclusion of the treated unit (Slovenia in our case) from the donor pool. Then the remaining units form a new donor pool that is used in such a way that each unit is treated as if the intervention occurred. The calculation of the difference between the actual outcome and the synthetic values forms the basis for verifying the null hypothesis that the intervention had no effect. In our case, the null hypothesis stipulates that the accession to the Eurozone had no impact on the complexity of Slovenian exports. That hypothesis would be proved wrong if the estimated treatment effects were different to the calculated placebo effects.

Figure 5 illustrates the results of the placebo test. The bold red line is the ECI (HP-filtered) gaps for Slovenia. The other lines are gaps for the placebo units. The placebo test was conducted using the MSCMT package in R, described in detail in Becker and Klößner (2017). We excluded from our analysis those control units that had pre-treatment RMSPE of more than 10 times the Slovenian pre-treatment RMSPE. In other words, we included only those placebo units that had a relatively good fit in the 1995-2006 period.

As Figure 5 illustrates, the gaps for Slovenia stood out. Those gaps were positive, while in the majority of placebo cases the gaps were negative. The only exception was Switzerland - that country had similar differences between the actual and synthetic values. However, we do not think it supports the null hypothesis of no intervention effects. The gap in Switzerland appeared before the year of intervention (the year of the adoption of the single currency by Slovenia). To be more precise, that gap was visible for the post-2005 years, indicating that other shocks could drive the behaviour of the Swiss ECI. 
Figure 5: Placebo test results for the Eurozone accession effects on Slovenia's ECI

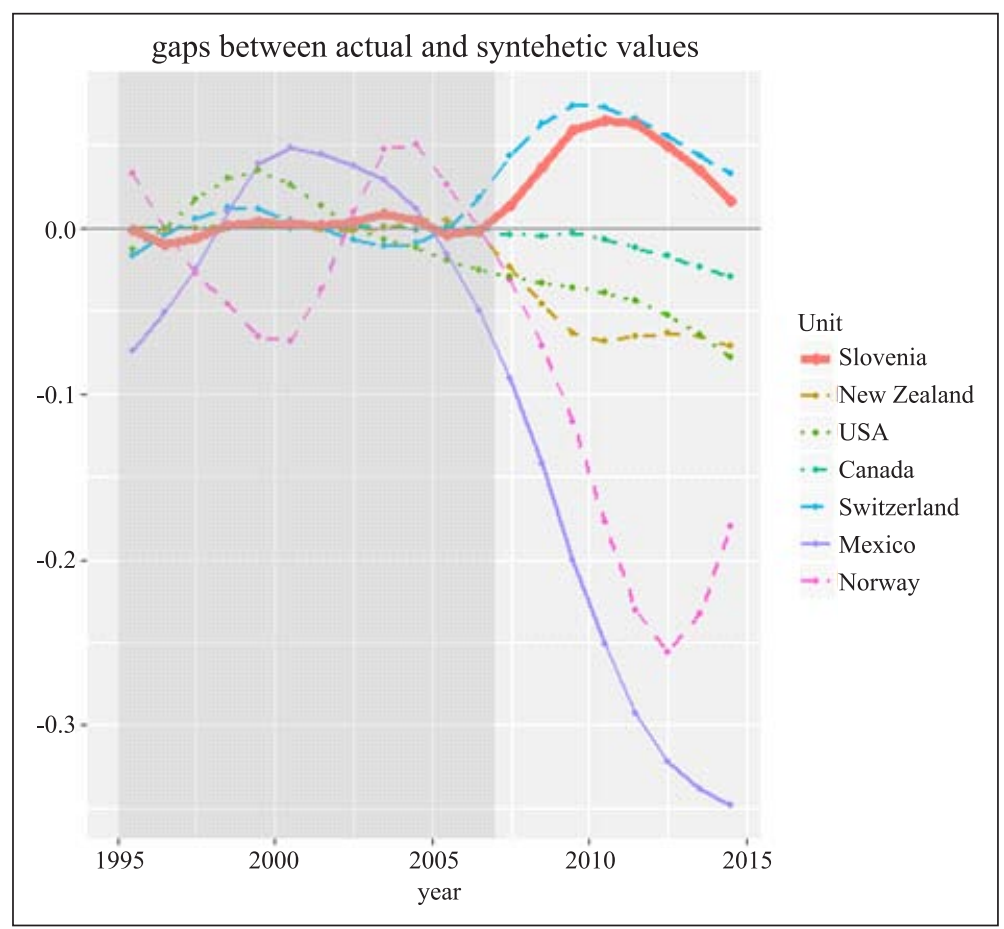

Source: Authors' calculation

Spillover effects from the 2004 EU enlargement may be a better explanation of the gap for Switzerland. Bearing that in mind, the placebo test may be seen as a proof that the introduction of the euro had an impact on Slovenian exports' complexity ${ }^{11}$.

\section{Results and discussion}

After decomposing the ECI series, it became apparent that Slovenian complexity of exports started decreasing when Slovenia joined the EU. These findings are consistent with results obtained by Young (1991) who claimed that as a result of lowering trade barriers in exchange with more developed countries the less

\footnotetext{
${ }^{11}$ In another attempt to test the robustness of the obtained findings, we have tried changing the treatment period from 2007 to 2004, which was the year of Slovenian accession to EU. As expected, in such a case, had Slovenia not joined the EU at all, SCM predicts a different, growing trend of ECI development, that would be temporarily hampered by the global crisis in 2007-2009, only to accelerate in 2010. Results are available on request.
} 
developed ones tend to focus on specialization in more traditional (thus less advanced and less complex) sectors.

Despite similar expected consequences for complexity, our data does not confirm the mechanism suggested by Galor and Mountford (2008), who claimed that less developed countries limit their investment in human capital after engagement in regional integration. Slovenian Human Capital Index manifested a steady growing trend throughout the entire research period and there are no indicators of a loss of dynamics ${ }^{12}$.

Our main result shows, however, that adopting euro caused another change of the trend. SCM algorithm predicts, that if it was not for implementing single currency, the synthetic ECI values would have continued their downfall until 2010 and then rebound to reach the values closer to actual around year 2015. Therefore, accessing Eurozone in 2007 stopped the ongoing decrease and allowed ECI to stabilise.

Similar patterns may be observed for net FDI inflow in Slovenia ${ }^{13}$. One may find that Slovenia had high net inflow before EU accession (anticipation effect), which had changed after Slovenia became a member state. Then the FDI inflow was rebuilding, as Slovenia was heading towards accessing the Eurozone, which again was stopped by the waves of crisis in 2008 and 2011. After the crisis Slovenia has quickly increased the net inflow of FDI. It seems then, that the ECI increase observed after adopting euro might be (at least partly) an effect of high inflow of FDI. In such a case, our results are consistent with those of $\mathrm{Xu}$ and $\mathrm{Lu}$ (2009), Harding and Javorcik (2012) and Eck and Hubert (2016), who proved that higher FDI inflows result in higher export sophistication. They are also consistent with the idea that economic integration allows higher FDI inflow (Antras and Foley, 2011).

Due to lack of the most recent data, it is uncertain, whether synthetic ECI would have stabilised after 2015 or continued its fluctuations. Nevertheless, joining monetary union definitely allowed the adjustment processes to be quicker and more efficient, without negative overshooting. We found no similar conclusions in the existing literature.

The policy implications of such results are clear. They suggest, that once a small country agrees to join a regional integration organisation, it might seem reasonable to stimulate as close an integration as possible. Stopping on the early stages seems inefficient, because it already causes an unfavourable change in specialization patterns, while at the same time it does not grant quicker adjustment and possible stimulation of export complexity.

\footnotetext{
$\overline{12}$ See Feenstra et al. (2015).

${ }^{13}$ See World Development Indicators.
} 


\section{Conclusion}

The aim of the article was to verify the impact of the euro adoption on the complexity of goods in Slovenian exports. To the best knowledge of the authors, this is the first attempt to assess the importance of an engagement in monetary integration for export complexity, hence the paper fills an important research gap. The analysis was conducted with the SCM procedure, which enables building counterfactual scenarios and observe synthetic national economy with assumption, that certain political decisions were different (e.g. that Slovenia did not join the Eurozone). It proved that accessing monetary union significantly altered the evolution path of the trend of Slovenian export complexity. By adopting the single currency, Slovenia achieved higher levels of export sophistication than it would in the counterfactual scenario and the stabilisation came quicker, thus the adjustment process was more efficient. Our results prove that monetary integration is nonnegligible for that feature of trade flows. They also have some policy implications. If a goal is to restructure the economy so that it could produce more sophisticated goods, since export complexity is correlated with economic growth, adoption of a single currency may facilitate such a process. Moreover, adopting euro stimulated ECI growth, while only EU accession was associated with a general drop of export complexity, as it may have caused a switch to less advanced specialization patterns. Our findings are consistent with the major trade theories. New EU member states are relatively less developed than the countries with longer history of integration, which forces them towards comparative advantages associated with lower technology levels and rather exploited learning-by-doing opportunities, thus lower ECI. They are also usually abundant in relatively cheap labour, which is utilized in the international labour division, discouraging quality upgrading of goods and also resulting in lower ECI. Adopting single currency hampered those processes, e.g. by attracting investment. Therefore, once it has been initiated, it is recommended to continue the process of regional integration.

\section{References}

Abadie, A., Diamond, A., Hainmueller, J. (2010) "Synthetic Control Methods for Comparative Case Studies: Estimating the Effect of California's Tobacco Control Program", Journal of the American Statistical Association, Vol. 105, No. 490, pp. 493-505, doi: 10.1198/jasa.2009.ap08746.

AEC, Atlas of Economic Complexity, Center for International Development at Harvard University, http://www.atlas.cid.harvard.edu.

Anand, R., Mishra, S., Spatafora, N. (2012) "Structural Transformation and the Sophistication of Production", IMF Working Paper No. 12/59, Washington, DC, doi: $10.5089 / 9781463937775.001$. 
Antras, P., Foley, F.C. (2011) "Regional Trade Integration and Multinational Firm Strategies". In Barro, R., Lee, J.-W. eds, Costs and Benefits of Economic Integration in Asia, Oxford: Oxford University Press, doi: 10.1093/acprof:o so/9780199753987.001.0001.

Aristovnik, A., Meze, E. (2009) “The Economic and Monetary Union's Effect on (International) Trade: The Case of Slovenia Before Euro Adoption", MPRA Paper No. 17445.

Auboin, M., Ruta, M. (2013) "The relationship between exchange rates and international trade: a literature review", World Trade Review, Vol. 12, No. 3, pp. 577-605, doi: 10.1017/S1474745613000025.

Baldwin, R. (2006) “The Euro's Trade Effects”, ECB Working Paper No. 594, Frankfurt am Main.

-------, DiNino, V. (2006) "Euros and zeros: The common currency effect on trade in new goods", NBER Working Papers No. 12673, doi: 10.3386/w12673.

-------, -------, Fontagné, L., De Santis, R., Taglioni, D. (2008) "Study on the Impact of the Euro on Trade and Investment", European Economy. Economic papers No. 321, Brussels, doi: 10.2765/65274.

Becker, M., Klößner, S. (2017) "Computing Generalized Synthetic Controls with R package MSCMT", Saarland University, mimeo, http://www.oekonometrie.unisaarland.de/papers/FastReliable.pdf.

Berger, H., Nitsch, V. (2008)“Zooming out: The trade effect of the euro in historical perspective", Journal of International Money and Finance, Vol. 27, No. 8, pp. 1244-1260, doi: 10.1016/j.jimonfin.2008.07.005.

Bergin, P., Lin, C.Y. (2012)“The dynamic effects of a currency union on trade", Journal of International Economics, Vol. 87, No. 2, pp. 191-204, doi: 10.1016/j. jinteco.2012.01.005.

Berman, N., Martin, P., Mayer, T. (2012) "How Do Different Exporters React to Exchange Rate Changes", Quarterly Journal of Economics, Vol. 127, No. 1, pp. 437-492, doi: 10.1093/qje/qjr057.

Campos, N. F., Coricelli, F., Moretti, L. (2014) "Economic Growth and Political Integration: Estimating the Benefits from Membership in the European Union Using the Synthetic Counterfactuals Method", IZA Discussion Paper No. 8162.

Chaney, T. (2016) "Liquidity constrained exporters", Journal of Economic Dynamics \& Control, Vol. 72, pp. 141-154, doi: 10.1016/j.jedc.2016.03.010.

Cieślik, A., Michałek, J., Michałek, A. (2013) “The Impact of the Common Currency on Exports on New EMU Members: Firm-level Evidence for Slovenia and Slovakia", Equilibrium. Quarterly Journal of Economics and Economic Policy, Vol. 8, No. 4, pp. 7-23, doi: 10.12775/EQUIL.2013.024.

, Mycielski J.(2012) "Trade effects of the euro adoption in Central and Eastern Europe", Journal of International Trade \& Economic Development, Vol. 21, No. 1, pp. 25-49. 
member states", Bank i Kredyt (Bank \& Credit), Vol. 45, No. 4, pp. 331-348.

Costinot, A. (2009) "On the origins of comparative advantage", Journal of International Economic, Vol. 77, No. 2, pp. 255-264, doi: 10.1016/j.jinteco. 2009.01.007.

-------, Oldensky, L., Rauch, J. E. (2009) "Adaptation and the Boundary of Multinational Firms", NBER Working Paper No. 14668, doi: 10.3386/w14668.

Crozet, M., Koenig, P., Rebeyrol, V. (2008) "Exporting to Insecure Markets: a Firm-Level Analysis", CEPII Working Paper No.2008-13, Paris.

Damijan, J., Konings, J., Polanec, S. (2013) "Pass-on trade: why do firms simultaneously engage in two-way trade in the same varieties?", Review of World Economics (Weltwirtschaftliches Archiv), Vol. 149, No. 1, pp. 85-111.

De Nardis, S., Vicarelli, C. (2003) "Currency Unions and Trade: The Special Case of EMU”, World Review of Economics, Vol. 139, No. 4, pp. 625-649, doi: 10.1007/BF02653107.

Eck, K., Huber, S. (2016) "Product sophistication and spillovers from foreign direct investment", Canadian Journal of Economics, Vol. 49, No. 4, pp. 1658-1684, doi: $10.1111 /$ caje. 12247.

Feenstra, R. C., Inklaar, R., Timmer, M. P. (2015) "The Next Generation of the Penn World Table", American Economic Review, Vol. 105, No. 10, pp. 3150-3182, doi: 10.1257/aer.20130954.

Flam, H.,Nordström, H. (2007) "Explaining large euro effects on trade: the extensive margin and vertical specialization", mimeo, https://www.researchgate. net/publication/228673756.

Fontagné, L., Mayer, T., Ottaviano, G. (2009) "Of markets, products and prices. The effects of the euro on European firms", Bruegel Blueprint Series, Vol. 8.

Frankel, J.A. (2010) "The Estimated Trade Effects of the Euro: Why Are They Below Those from Historical Monetary Unions among Smaller Countries?". In Alesina, A., Giavazzi, F. eds, Europe and the Euro, Chicago: University of Chicago Press, doi: 10.3386/w14542.

Fremeth, A. R., Holburn, G. L. F., Richter, B. K. (2013) "Making Causal Inferences in Small Samples using Synthetic Control Methodology: Did Chrysler Benefit from Government Assistance?", Social Science Research Network, doi: $10.2139 /$ ssrn. 2135294.

Galor, O., Mountford, A. (2008) "Trading Population for Productivity: Theory and Evidence", Review of Economic Studies, Vol. 75, No. 4, pp. 1143-1179, doi: 10.1111/j.1467-937X.2008.00501.x.

Gertler, P. (2006) "Export Structure Quality and Economic Growth", National Economy Issues, National Bank of Slovakia, BIATEC, Vol. XIV, No. 10. 
Glick, R., Rose, A. (2016) "Currency Unions and Trade: A Post-EMU Mea Culpa", CEPR Discussion Paper No. 10615, London.

Gomis-Porqueras, P., Puzzello, L. (2015) "Winners and Losers from the euro", Deakin University, Faculty of Business and Law Economics Series No. 2015_2.

Harding, T., Javorcik, B. (2012) "Foreign Direct Investment and Export Upgrading", Review of Economics and Statistics, Vol. 94, No. 4, pp. 964-980, doi: 10.1162/ REST_a_00226.

Hausmann, R., Hwang, J., Rodrik, D. (2005)"What you export matters", NBER Working Paper No. 11905.

------, -------, ------ (2007) "What you export matters", Journal of Economic Growth, Vol. 12, No. 1, pp. 1-25, doi: 10.1007/s10887-006-9009-4.

, Klinger, B. (2007) "The Structure of the Product Space and the Evolution of Comparative Advantage", Center for International Development at Harvard University Working Paper No. 146, Cambridge, MA.

Hidalgo, C.A., Hausmann, R. (2009) "The building blocks of economic complexity", Proceedings of the National Academy of Sciences, 106(26), pp. 10570-10575, doi: 10.1073/pnas.0900943106.

(2011) "The network structure of economic output", Journal of Economic Growth, 16 (4), pp. 309-342, doi: 10.1007/s10887-011-9071-4.

Ito, T., Okubo, T. (2016) "The Impact of the Euro on the Quality of Trade: Evidence from the European Union", The Manchester School, Vol. 84, No. 4, pp. 506527, doi: 10.1111/manc.12112.

Kaul, A., Klößner, S., Pfeifer, G., Schieler, M. (2016) "Synthetic Control Methods: Never Use AllPre-Intervention Outcomes as Economic Predictors", mimeo.

Koren, M., Tenreyro, S. (2013) "Technological Diversification", The American Economic Review, 103(1), pp. 378-414, doi: 10.1257/aer.103.1.378.

Lall, S. (2000) "The Technological Structure and Performance of Developing Country Manufactured Exports, 1985-1998", University of Oxford Queen Elizabeth House Working Paper No. 44, Oxford.

Lederman, D., Maloney, W. F. (2012) "Does What You Export Matter? In Search of Empirical Guidance for Industrial Policies", World Bank, Washington, DC, doi: 10.1596/978-0-8213-8491-6.

Mayer, T., Zignago, S. (2011) "Notes on CEPII's distances measures: The GeoDist database", CEPII Working Paper No. 2011-25, Paris.

Melitz, M. J. (2003) "The Impact of Trade on Intra-Industry Reallocations and Aggregate Industry Productivity", Econometrica, Vol. 71, No. 6, pp. 16951725, doi: 10.1111/1468-0262.00467.

Micco, A., Ordoñez, E., Stein, G. (2003) "The Currency Union Effect on Trade: Early Evidence from EMU", Economic Policy, Vol. 18, No. 37, pp. 315-356, doi: 10.1111/1468-0327.00109_1. 
Mundell, R.A. (1961) “A Theory of Optimum Currency Areas”, The American Economic Review, Vol. 51, No. 4, pp. 657-665.

Nitsch, V. (2011) "Monetary Integration and Trade: What Do We Know?" [in:] Volz, U. (ed.) "Regional Economic Integration Beyond Europe", Edward Elgar Publishing, Northampton, MA, doi: 10.4337/9781849809153.00024.

Rose, A. (2000) "One money, one market: The effect of currency unions on trade", Economic Policy, Vol. 15, No. 30, pp. 7-46, doi: 10.1111/1468-0327.00056.

Saia, A. (2016) "Choosing the Open Sea: The Cost to the UK of Staying Out of the euro", University of Bologna, mimeo.

Santos Silva, J., Tenreyro, S.(2006) "The Log of Gravity", Review of Economics and Statistics, Vol. 88, No. 4, pp. 641-658, doi: 10.1162/rest.88.4.641.

(2010) "Currency Unions in Prospect and Retrospect", Annual Review of Economics, Vol. 2, pp. 51-74, doi: 10.1146/annurev.economics.102308.124508.

Segura-Cayuela, R., Vilarrubia, J. M. (2008) "Uncertainty and entry into export markets", Banco de España Working Paper No. 0811, Social Science Research Network, doi: 10.2139/ssrn.1144564.

World Development Indicators, World Bank: World Data Bank, http://databank. worldbank.org $/$ data/reports.aspx ? source $=2 \&$ series $=$ BX.KLT.DINV.CD. WD\&country $=$.

Worldwide Governance Indicators, World Bank: World Data Bank, http://databank. worldbank.org/data/reports.aspx?source=worldwide-governance-indicators.

$\mathrm{Xu}, \mathrm{B}$., Lu, J. (2009) "The impact of foreign firms on the sophistication of Chinese exports", China Economic Review, Vol. 20, No. 3, pp. 425-439, doi: 10.1016/j. chieco.2009.01.004.

Yeaple S. (2005) "A simple model of firm heterogeneity, international trade, and wages". Journal of International Economics, Vol. 65, No. 1, pp. 1-20, doi: 10.1016/j.jinteco.2004.01.001.

Young, A. (1991) "Learning by Doing and the Dynamic Effects of International Trade", Quarterly Journal of Economics, Vol. 106, No. 2, pp. 369-405, doi: $10.2307 / 2937942$.

Žúdel, B, Melioris L. (2016) "Five Years in Balloon: Estimating the Effects of Euro Adoption in Slovakia Using the Synthetic Control Method", OECD Economics Department Working Paper No. 1317, Paris. 


\title{
Utjecaj usvajanja eura na složenost robe u slovenskom izvozu ${ }^{1}$
}

\author{
Piotr Gabrielczak ${ }^{2}$, Tomasz Serwach ${ }^{3}$
}

\begin{abstract}
Sažetak
Cilj ovog rada je provjeriti utjecaj usvajanja eura na strukture dobara u slovenskom izvozu. Prema najboljim saznanjima autora, ovo je prva studija o posljedicama koje ukidanje nacionalne valute može imati za tu značajku trgovine. Prema modelima trgovine Ricarda i Hechscher-Ohlina, takva odluka o politici (koja se vidi kao primjer liberalizacije trgovine) može dovesti do specijalizacije u proizvodnji više ili manje sofisticiranih dobara - ono što ovisi o tehnologiji i faktorima dodjele sredstava. Istodobno, povećani tokovi izravnih stranih ulaganja mogu učiniti određenu ekonomiju više angažiranom u međunarodnim proizvodnim lancima, $s$ dvosmislenim utjecajem na složenost izvoza. Sobzirom na činjenicu da je nemoguće (a priori) teoretski predvidjeti utjecaj monetarne integracije na složenost, razumljivo je empirijski tražiti učinke integracije. Autori su koristili Sustav za kontrolu sintetske metode kako bi usporedili stvarne razine izvozne složenosti u Sloveniji nakon usvajanja eura sa suprotnim scenarijem u kojem Slovenija ne ulazi u Eurozonu. Rezultati ukazuju da je članstvo u Europskoj monetarnoj uniji (EMU) dovelo do privremenog povećanja složenosti izvezene robe.
\end{abstract}

Ključne riječi: Eurozona, euro, izvoz, Slovenija, složenost, metoda sintetičke kontrole, komparativna prednost, faktor obilja

JEL klasifikacija: C21, F14, F15

1 Istraživački projekt financira Nacionalni znanstveni centar Poljske (Narodowe Centrum Nauki), dodijeljen na temelju odluke DEC-2014/13/N/HS4/02977 (broj ugovora: UMO-2014/13/N/ HS4/02977).

2 Docent, Faculty of Economics and Sociology, Katedra za makroekonomiju, 3/5 POW Street, room A416, 90-255 Lodz, Poljska. Znanstveni interes: međunarodna ekonomija, poslovni ciklusi.Tel.: +4842635 5058. Fax: +4842635 5308. E-mail:pgabrielczak@uni.lodz.pl.

3 Docent, Faculty of Economics and Sociology, Katedra za međunarodno poslovanje, 3/5 POW Street, room A216, 90-255 Lodz, Poljska. Znanstveni interes: međunarodno poslovanje, gospodarski rast.Tel.: +4842635 5353. Fax: +4842635 5210.E-mail: serwachtomasz@uni. lodz.pl. 